\title{
Market Interdependence In The Pacific Basin Region: Internal Drives And External Influences
}

Ali F. Darrat, Ph.D., Louisiana Tech University, USA

Grant Colthup, Tactical Global Management, Brisbane, Australia

Bin Li, Ph.D., Griffith University, Brisbane, Australia

Maosen Zhong, Pureland Learning College, Toowoomba, Australia

\begin{abstract}
This paper examines equity market linkages in the Pacific Basin (PB) region and their relations to other mature markets and also assesses the response of these markets to major global events. Results from weekly data for market pairs and for the region as a whole consistently suggest that markets in the $P B$ region are internally interdependent and exhibit significant external relations mainly with the US (rather than Japan). The presence of potent market linkages seems inconsistent with market efficiency provided that implied trading rules yield risk-adjusted excess returns. However, the results further indicate that $P B$ market linkages, both internally within the region and externally with the US, have endured considerable weaknesses particularly since the September 11, 2001 terrorist attack. Such recent weakening of equity market linkages may have strengthened diversification benefits available to US investors from investing in the PB region. We also obtain evidence indicating that three main factors significantly explain the differing degrees of market linkages across countries in the PB region; namely, exchange-rate volatility, equity market volatility and money-market interlink.
\end{abstract}

Keywords: Equity Market Linkages; Cointegration Analysis; September 11 Terrorist Attack; Asian Financial Crisis; Pacific-Basin Equity Markets

\section{INTRODUCTION}

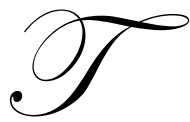

he past several decades have witnessed immense changes in the financial markets of the PacificBasin region, including the removal of capital restrictions, currency floating, improved information technology, enhanced investor education, increased labor mobility, and growing tendencies towards globalization. Such changes may have enhanced market linkages in the region which in turn reduced potential benefits from international diversification. The level of financial market linkage could also impact the optimal corporate capital structure through differing costs of capital (Cooper and Kaplanis, 2000). In addition, Bekaert, Harvey and Lundblad (2005) report that market liberalization promotes economic growth through increased equity market linkages.

Research on equity market linkages is divisible into several groups. The first employs international CAPMs to test if assets are priced by domestic, regional or global factors. Representing this group are Bekaert and Harvey (1995), De Santis and Imrohoroglu (1997), Ng (2004), and Antell and Vaihekoski (2007). The second group of studies such as Kearney (2000), Koutmos and Booth (1995), $\mathrm{Ng}$ (2000), and Baele (2005) focus on volatility spillovers across equity markets. Another research direction examines contagion effects, primarily whether markets become more interdependent due to important events. Examples are Claessens and Forbes (2001), Forbes and Rigobon (2002), Hon, Strauss and Yong (2004), and Chiang, Jeon and Li (2007).

Prior research uses a variety of ways for measuring market linkages including correlation and cointegration techniques. For example, while Ammer and Mei (1996) focus on contemporaneous covariance, Bekaert and Harvey 
(1995) use conditional covariance, and Bracker, Docking and Koch (1999) use Geweke's feedback procedure. Other studies use instead the cointegration methodology to examine equity market linkages. Examples include Phylaktis (1999), Grewal, Mills, Mehta and Mujumdar (2001) and Darrat and Zhong (2005). We follow this third strand of research and employ the cointegration approach to investigate equity market linkages in the Asian Pacific Basin (PB) region. As Kasa (1992) and Darrat and Zhong (2005) point out, contemporaneous correlations do not reflect genuine information on market interrelationships and they are likely misleading if investors have long holding periods. Since international diversification is a long-term investment strategy, results in such studies that only address market linkages over short-term horizons as Dekker, Sen and Young (2001) and Johnson and Soenen (2002) might not be useful.

The PB markets provide a testing ground whether some key events such as the September 11 terrorist attack of 2001 and the Asian financial crisis affect the long-run market linkage. Moreover, due to the relative ease of financial regulations and the increase in foreign direct investment to the PB region in recent years, most PB markets have been more liberalized and have become an important force in the global financial market.

This paper contributes to the literature in several ways. First, apart from studying the long-run market linkage in the Asian Pacific region, this inquiry also examines if and to what extent market linkages in the PB region have been influenced by the two largest markets in the world; namely, the Japanese and US markets. Contrary to Ghosh, Saidi, and Johnson (1999) and Phylaktis (1999), the empirical results of this paper corroborate those of Darrat and Zhong (2002) and consistently suggest that market linkages in the PB region are primarily driven by the US rather than Japan.

Second, this paper focuses on the time variation of equity market linkages. Bekaert and Harvey (1995) report evidence showing significant time variations in the level of global market integration over time. Longin and Solnik (1995) find that conditional correlations among seven matured equity markets have strengthened over time especially during periods of high conditional volatilities. Siklos and $\mathrm{Ng}$ (2001) find no support for the contention that the long-run equilibrium relation linking the US market with several Asian markets remains invariable over time. Darrat, Gilley, Li and Wu (2010) also report that the relative risk aversion relation in the Asian Pacific region underwent significant changes due to the 1997 Asian crisis. This paper provides another piece of evidence indicating that linkages among the PB markets have endured considerable changes due to the 1997 Asian financial crisis and the terrorist attack of September 11, 2001.

Third, an attempt is made here to identify factors responsible for linking equity markets across national borders within the PB region. A growing body of literature suggests that the evolution of market linkages among different countries tends to be associated with international trade and certain other macroeconomic factors. For example, Roll (1992) suggests that industrial structure significantly affects international stock prices, while Phylaktis and Ravazzolo (2002) underscore the importance of economic and trade ties for stock market linkages across countries. Darrat and Zhong (2005) report evidence that trade accords play a significant role in strengthening equity market linkages. Among several potential factors, the results suggest that exchange-rate volatility, equity market volatility and money-market interlinks significantly explain the differing degrees of market linkages across countries in the region.

The rest of the paper is organized as follows. Section 2 discusses the data while Section 3 highlights the methodology and presents the empirical results. Section 4 pursues further analysis of equity market linkage using cross-sectional regressions. Section 5 concludes the paper.

\section{DATA AND SUMMARY STATISTICS}

The data are weekly observations comprising eleven national stock indexes in the Pacific Basin region (including Japan) plus the US. The sample covers twenty one years from January $5^{\text {th }}, 1988$ through to December $30^{\text {th }}, 2008$ (1096 observations for each country). The national stock indexes are: the Australian DS market index (Australia), Hang Seng (Hong Kong), Jakarta Composite (Indonesia), Nikkei 225 (Japan), Seoul Composite (Korea), KLCI Composite (Malaysia), New Zealand DS market index (New Zealand), PSE Composite (the Philippines), Straits Times DS-calculated market index (Singapore), Taiwan SE Weighted (Taiwan), Bangkok SET (Thailand), 
and S\&P 500 (the US). All data come from DataStream. This paper uses weekly rather than daily data since the weekly data can reduce the effects of non-synchronous trading hours between the US and other markets in the PB region. Each week runs from Tuesday to next Tuesday to avoid possible biases of the weekend effect. With the national stock indexes expressed in natural logarithms, their first differences represent continuously compounding returns.

Table 1: Summary Statistics of National Stock Index Returns and Their Correlations

\begin{tabular}{|c|c|c|c|c|c|c|c|c|c|c|c|c|}
\hline \multirow[b]{2}{*}{ Country } & \multicolumn{12}{|c|}{ Panel A: Summary Statistics } \\
\hline & Mean & \multicolumn{2}{|c|}{ Std.Dev. } & Median & \multicolumn{2}{|c|}{ Minimum } & Maximum & Rho(1) & Rho(12) & \multicolumn{2}{|c|}{$\mathbf{Q}(\mathbf{2 4})$} & Qsignif \\
\hline $\mathrm{AU}$ & 0.092 & \multicolumn{2}{|c|}{2.111} & 0.234 & -14.226 & & 10.467 & -0.091 & 0.002 & \multicolumn{2}{|c|}{28.840} & 0.23 \\
\hline HK & 0.162 & \multicolumn{2}{|c|}{3.839} & 0.318 & -31.409 & \multicolumn{2}{|r|}{17.473} & -0.038 & -0.057 & \multicolumn{2}{|c|}{46.137} & 0.00 \\
\hline ID & 0.255 & \multicolumn{2}{|c|}{5.097} & 0.345 & -34.277 & & 89.720 & -0.080 & -0.027 & \multicolumn{2}{|c|}{42.060} & 0.01 \\
\hline JP & -0.081 & \multicolumn{2}{|c|}{3.091} & 0.017 & -19.966 & & 17.885 & -0.028 & 0.002 & \multicolumn{2}{|c|}{20.503} & 0.67 \\
\hline $\mathrm{KO}$ & 0.069 & \multicolumn{2}{|c|}{4.215} & 0.158 & -19.186 & & 18.180 & -0.033 & -0.017 & \multicolumn{2}{|c|}{19.333} & 0.73 \\
\hline MY & 0.106 & \multicolumn{2}{|c|}{3.497} & 0.142 & -21.026 & & 28.566 & -0.014 & -0.068 & & & 0.05 \\
\hline $\mathrm{NZ}$ & 0.059 & & 09 & 0.143 & -17.605 & & 17.003 & -0.061 & 0.022 & & & 0.00 \\
\hline PP & 0.076 & & 87 & 0.004 & -21.666 & & 18.525 & 0.006 & -0.003 & & & 0.11 \\
\hline SG & 0.070 & & 24 & 0.173 & -14.445 & & 13.077 & 0.002 & 0.001 & & & 0.12 \\
\hline TA & 0.061 & & 30 & 0.493 & -24.308 & & 19.545 & 0.049 & 0.018 & & & 0.03 \\
\hline $\mathrm{TH}$ & 0.036 & & 68 & 0.013 & -19.034 & & 27.840 & 0.040 & -0.016 & & & 0.02 \\
\hline US & 0.113 & & 44 & 0.299 & -15.766 & & 12.375 & -0.134 & -0.025 & & & 0.00 \\
\hline & & & & & Panel & B: $C$ & Correlation & Matrix & & & & \\
\hline Country & $\mathbf{A U}$ & HK & ID & JP & KO & MY & NZ & PP & SG & TA & TH & US \\
\hline $\mathrm{AU}$ & 1 & 0.58 & 0.30 & 0.49 & 0.34 & 0.40 & 0.55 & 0.40 & 0.53 & 0.33 & 0.35 & 0.47 \\
\hline HK & & 1 & 0.34 & 0.43 & 0.43 & 0.50 & 0.41 & 0.47 & 0.66 & 0.35 & 0.49 & 0.39 \\
\hline ID & & & 1 & 0.25 & 0.25 & 0.34 & 0.19 & 0.38 & 0.38 & 0.12 & 0.34 & 0.15 \\
\hline JP & & & & 1 & 0.40 & 0.34 & 0.32 & 0.29 & 0.48 & 0.32 & 0.32 & 0.40 \\
\hline $\mathrm{KO}$ & & & & & 1 & 0.3 & 0.22 & 0.30 & 0.44 & 0.32 & 0.39 & 0.27 \\
\hline MY & & & & & & 1 & 0.35 & 0.40 & 0.55 & 0.28 & 0.48 & 0.27 \\
\hline NZ & & & & & & & 1 & 0.31 & 0.38 & 0.25 & 0.27 & 0.31 \\
\hline PP & & & & & & & & 1 & 0.49 & 0.31 & 0.46 & 0.25 \\
\hline SG & & & & & & & & & 1 & 0.37 & 0.54 & 0.40 \\
\hline TA & & & & & & & & & & 1 & 0.29 & 0.23 \\
\hline $\mathrm{TH}$ & & & & & & & & & & & 1 & 0.27 \\
\hline US & & & & & & & & & & & & 1 \\
\hline
\end{tabular}

Notes: The full period covers January 5, 1988 through to December 30, 2008. The returns are weekly continuously compounded returns. The values of mean, std.dev, median, minimum and maximum are multiplied by 100 . The abbreviations used for the different markets are as follows: AU $\rightarrow$ Australia, HK $\rightarrow$ Hong Kong, ID $\rightarrow$ Indonesia, JP $\rightarrow$ Japan, KO $\rightarrow$ Korea, MY $\rightarrow$ Malaysia, NZ $\rightarrow$ New Zealand, PP $\rightarrow$ the Philippines, SG $\rightarrow$ Singapore, TA $\rightarrow$ Taiwan, TH $\rightarrow$ Thailand and US $\rightarrow$ the United States. Qsignif is the significance of the Ljung-Box Q statistic with 24 lags.

Panel A of Table 1 provides statistics for the twelve returns series. The Indonesian stock market displays the highest mean return of $0.255 \%$ as well as the highest variance over the sample period. Australia has the lowest variance while the US has the second lowest variance with a mean return of 0.092 for Australia and 0.113 for the US. The data show that Japan is the only market in the sample period with a negative mean return. The correlation matrix assembled in panel B of Table 1 indicates that all markets in the sample are strongly and positively correlated with each other, especially among Australia, Hong Kong, New Zealand, Singapore and the US. As shown below, such strong contemporaneous correlations between market pairs do not necessarily imply the absence of significant gains from international diversifications. In addition, these simple correlations may be temporary in nature and could drastically change with market volatility (Longin and Solnik, 1995).

Following prior research (e.g., Grewal et al., 2001; Srivastava, 2007; Subramanian, 2008; and Herwany and Febrian, 2009), we assess the linkage among the Pacific Basin markets using the cointegration metric. A necessary prelude to cointegration testing is to examine the data for the presence of unit roots. Results from the Augmented Dickey-Fuller and Philips-Perron tests (available upon request) suggest that all stock indexes (in logs) are nonstationary and become stationary after first-differencing [i.e., all series are I (1)]. 


\section{METHOD AND RESULTS}

\subsection{Cointegration Analysis}

Monte Carlo evidence in Cheung and Lai (1993) suggests the relative robustness of the trace over the maximal eigenvalues statistics of Johansen and Juselius (1992, JJ) for testing cointegration. The trace statistic is computed as:

$$
-T \sum_{i=r+1}^{n} \log \left(1-\hat{\lambda}_{i}\right)
$$

where $T=$ the number of observations, $n=$ the number of variables in the test, $r=$ the number of independent linear cointegrating vectors, and $\hat{\lambda}_{i}=$ the $i^{\text {th }}$ smallest squared canonical correlation in Johansen and Juselius (1992). The 95\% and 90\% critical values come from Table C.1 of Dennis, Hansen, Johansen and Juselius (2005).The first series of tests are bivariate tests between the sixty-six unique market pairs based on the full sample period (Jan. $5^{\text {th }} 1988$ to Dec. $30^{\text {th }} 2008$ ). Five lags in the underlying testing models were sufficient to whiten the residuals (higher lags produced similar results).

The results in Table 2 (Panel A) reveal that only thirteen (out of 66) market pairs have significant cointegrating relations at the $90 \%$ level. Notable among these cases is the potent cointegrating relations that Taiwan carries in the region, perhaps owing to strong trade flows that Taiwan has had with other PB countries since the 1990s.

Gregory and Hansen (1996) and Hatanaka (1996) find evidence showing the sensitivity of the JJ test to the presence of regime shifts. One way to deal with this problem is to conduct the JJ test on two separate regimes. A potential cause of possible shifts in the PB region is the September 11, 2001 terrorist attack. We divide the sample into pre-9/11 (Jan. 5, 1988 to Sept. 4, 2001) and post-9/11 attack (Sept. 10, 2002 to Dec. 30, 2008) periods. The tests exclude one year after the attack to clearly differentiate the two sub-periods. We then perform another round of bivariate cointegration tests for the sixty-six market pairs over the two sub-periods.

Table 2 (panels B and C) reports the results from the JJ test on all market pairs for the pre- and post-9/11 periods. While several market pairs in the region (10 internal pairs) possessed potent cointegrating relations prior to September 2001, the number of market pairs exhibiting significant interdependence has been drastically reduced (only 4 internal pairs). Besides adversely affecting internal linkages in the PB region, the September 2001 attack has also weakened the external relations of the region with the US. While the US market in the pre-9/11 regime had strong cointegrating relations with at least 8 markets in the region, such potent long-run relations appeared to have all but vanished in the period following the September 11 attack $^{1}$.

However, the above inferences from cointegration tests in a bivariate context could be contaminated with possible omission-of-variable biases (Darrat, 1994). Therefore, our focus next turns to multivariate cointegrating relations. Table 3 (Panel A) reports the JJ multivariate test results for the twelve markets over the full period. Unlike the relatively feeble bivariate cointegration results (see Table 2, panel A), the multivariate results support the presence of at least three potent cointegrating vectors binding together the PB markets internally, and also regionally with other matured markets.

\footnotetext{
${ }^{1}$ Results from Juselius' (1995) dummy-variable cointegration test (see Table 3, Panels D and E) suggest that both September 11, 2001 and the 1997 Asian financial crisis have significantly influenced the PB market linkages. Thus, similar to the 9/11 event, we also conduct sub-sample tests for the Asian crisis. The sample is divided into pre-crisis (Jan. 5, 1988 to Oct. 3, 1997) and postcrisis (Jan. 1, 1999 to Dec. 30, 2008) periods. The results (available upon request) indicate that while there are 8 significant internal cointegrating relations before the Asian crisis, only 6 exist after the crisis. In addition, there are at least 9 significant external cointegrating relations with the US before the crisis, but none thereafter. These results confirm that the Asian crisis has also impacted the PB market linkages both internally within the region and externally with the US market.
} 
Table 2: Trace Statistics from Bivariate Cointegration Tests

\begin{tabular}{|c|c|c|c|c|c|c|c|c|c|c|c|c|}
\hline \multicolumn{13}{|c|}{ Panel A: Full Sample (Jan 5,1988 - Dec. 30, 2008) } \\
\hline & $\mathrm{AU}$ & $\mathrm{HK}$ & ID & JP & $\mathrm{KO}$ & MY & NZ & $\mathrm{PP}$ & SG & TA & TH & US \\
\hline $\mathrm{AU}$ & & 9.99 & 17.21 & 13.26 & 10.72 & 12.45 & 15.17 & 9.05 & 11.25 & 17.13 & 11.15 & 14.66 \\
\hline HK & & & 12.58 & 13.75 & 11.33 & 15.23 & 12.26 & 12.56 & 12.73 & $18.38^{*}$ & 16.02 & 11.90 \\
\hline ID & & & & 13.80 & $23.33^{* *}$ & 14.57 & $20.66^{* * *}$ & 12.51 & $21.47^{* *}$ & $21.24^{* *}$ & 13.75 & 13.16 \\
\hline JP & & & & & 7.97 & 12.65 & 10.24 & 7.86 & 9.82 & 16.85 & 8.01 & $18.85^{*}$ \\
\hline $\mathrm{KO}$ & & & & & & 17.89 & 9.92 & 9.15 & 15.02 & $18.04^{*}$ & 7.28 & 13.79 \\
\hline MY & & & & & & & 13.34 & $18.59^{*}$ & $18.14^{*}$ & $20.52^{* *}$ & 17.12 & 14.83 \\
\hline $\mathrm{NZ}$ & & & & & & & & 9.07 & 10.83 & 17.46 & 9.42 & 12.59 \\
\hline PP & & & & & & & & & 9.39 & $18.76^{*}$ & 12.57 & 13.19 \\
\hline SG & & & & & & & & & & 16.87 & 8.69 & 14.18 \\
\hline TA & & & & & & & & & & & $18.89^{*}$ & $23.47^{* *}$ \\
\hline $\mathrm{TH}$ & & & & & & & & & & & & 17.70 \\
\hline \multicolumn{13}{|c|}{ Panel B: Pre-9/11 Sample (Jan. 5,1988 - Sep. 4, 2001) } \\
\hline & AU & HK & ID & JP & $\mathrm{KO}$ & MY & $\mathrm{NZ}$ & $\mathrm{PP}$ & SG & TA & TH & US \\
\hline $\mathrm{AU}$ & & 9.79 & $19.06^{*}$ & 14.64 & 11.03 & 10.69 & 9.95 & 8.49 & 12.03 & 13.09 & 13.44 & $21.06^{* * *}$ \\
\hline HK & & & $18.78^{*}$ & 12.08 & 12.04 & 11.17 & 13.36 & 8.98 & 14.70 & 14.16 & 11.69 & 14.13 \\
\hline ID & & & & $18.01^{*}$ & $22.98^{* *}$ & $19.87^{*}$ & $21.32^{* *}$ & $19.39 *$ & $22.18^{* *}$ & $23.26^{* * *}$ & $18.08^{*}$ & $24.71^{* *}$ \\
\hline JP & & & & & 10.10 & 9.03 & 9.26 & 6.35 & 10.96 & 11.69 & 5.56 & $20.33^{* *}$ \\
\hline $\mathrm{KO}$ & & & & & & 16.69 & 10.73 & 8.74 & 13.21 & 17.70 & 9.68 & $19.71^{*}$ \\
\hline MY & & & & & & & 11.66 & 13.36 & 17.74 & 15.91 & 13.10 & $18.02^{*}$ \\
\hline $\mathrm{NZ}$ & & & & & & & & 12.64 & 13.35 & 13.96 & 9.60 & 17.16 \\
\hline $\mathrm{PP}$ & & & & & & & & & 9.91 & 14.49 & 7.94 & 17.68 \\
\hline SG & & & & & & & & & & 15.33 & 9.76 & $19.18^{*}$ \\
\hline TA & & & & & & & & & & & 14.34 & $21.59^{* *}$ \\
\hline TH & & & & & & & & & & & & $21.65^{* *}$ \\
\hline
\end{tabular}

\begin{tabular}{|c|c|c|c|c|c|c|c|c|c|c|c|c|}
\hline \multicolumn{13}{|c|}{ Panel C: Post-9/11 Sample (Sep. 10, 2002 - Dec. 30, 2008) } \\
\hline & $\mathrm{AU}$ & HK & ID & $\mathrm{JP}$ & $\mathrm{KO}$ & MY & $\mathrm{NZ}$ & $\mathrm{PP}$ & SG & TA & TH & US \\
\hline $\mathrm{AU}$ & & 12.44 & 11.39 & $18.03^{*}$ & 9.64 & 8.12 & $18.74^{*}$ & 11.18 & 11.26 & 11.76 & 11.79 & 18.62 \\
\hline HK & & & 13.44 & 12.56 & 10.95 & 14.90 & 14.57 & 14.97 & 12.62 & $20.36^{* * *}$ & 12.65 & 17.64 \\
\hline ID & & & & 13.08 & 12.82 & 12.15 & 14.45 & $18.31^{*}$ & 12.73 & 12.21 & 13.93 & 16.34 \\
\hline JP & & & & & 7.92 & 10.66 & 8.96 & 13.44 & 12.12 & 9.48 & 9.10 & 11.77 \\
\hline $\mathrm{KO}$ & & & & & & 9.19 & 15.03 & 12.91 & 10.94 & 7.85 & 11.28 & 12.14 \\
\hline MY & & & & & & & 13.52 & 13.90 & 9.80 & 15.89 & 10.27 & 14.72 \\
\hline $\mathrm{NZ}$ & & & & & & & & 14.18 & 14.49 & 8.52 & 8.24 & 8.81 \\
\hline $\mathrm{PP}$ & & & & & & & & & 13.32 & 8.56 & 9.48 & 11.81 \\
\hline SG & & & & & & & & & & 12.70 & 13.79 & 15.75 \\
\hline TA & & & & & & & & & & & 9.03 & 11.22 \\
\hline $\mathrm{TH}$ & & & & & & & & & & & & 8.81 \\
\hline
\end{tabular}

Notes: See notes to Table 1. The trace statistics are the Johansen-Juselius (1992) bivariate cointegration tests. An ${ }^{* * *}$ and $*$ denote significance at the $95 \%$ and $90 \%$ levels, respectively. The critical values are from Table C.2 of Dennis et al. (2005). Five lags are used which whitened the residuals.

Several prior studies investigate the relative role that the Japanese and the US markets play in the PacificBasin region. As $\mathrm{Ng}$ (2000) points out, understanding the external origin of significant market movements is necessary to efficiently price domestic securities and to implement global hedging strategies. However, the available evidence on this important issue is mixed. For example, Phylaktis (1999) suggest that markets in the region are more closely related to the Japanese rather than to the US market, a verdict that is directly opposite to that of Darrat and Zhong (2002). Still, Ghosh, Saidi and Johnson (1999) contend that neither Japan nor the US drives all markets in the region. Note, however, that Darrat and Zhong's results are derived from multivariate JJ tests while Ghosh, Saidi and Johnson's findings are based on the bivariate Engle-Granger (1987) test. 
Table 3: External Influences on Equity Market Interdependence in the Pacific Basin Region: The Relative Role of the Japanese and US Markets

\begin{tabular}{|c|c|c|c|c|c|c|c|c|c|c|c|c|}
\hline \multicolumn{2}{|c|}{$\begin{array}{c}\text { Panel A: } \\
\text { All } 12 \text { markets }\end{array}$} & \multicolumn{2}{|c|}{$\begin{array}{c}\text { Panel B: } \\
\text { When Japan is } \\
\text { excluded }\end{array}$} & \multicolumn{2}{|c|}{\begin{tabular}{|c|} 
Panel C: \\
When the US \\
is excluded
\end{tabular}} & \multicolumn{2}{|c|}{ Critical Values } & \multicolumn{2}{|c|}{$\begin{array}{c}\text { Panel D: } \\
\text { Full sample with } \\
\text { the Asian crisis } \\
\text { dummy }\end{array}$} & \multicolumn{2}{|c|}{\begin{tabular}{|l} 
Panel E: \\
Full sample with \\
the $9 / 11$ dummy
\end{tabular}} & \multirow[t]{2}{*}{$95 \%$ Critical Values } \\
\hline $\begin{array}{l}\text { Null } \\
r=0\end{array}$ & $373.72^{\text {*** }}$ & Null & & Null & & $\begin{array}{c}95 \% \\
348.85\end{array}$ & $\begin{array}{c}90 \% \\
340.38\end{array}$ & $\begin{array}{l}\text { Null } \\
r=0\end{array}$ & $395.40^{\text {*** }}$ & $\begin{array}{l}\text { Null } \\
r=0\end{array}$ & $386.11^{* *}$ & \\
\hline$r \geq 1$ & $301.75^{* *}$ & $\mathrm{r}=0$ & $322.33^{\text {*** }}$ & $\mathrm{r}=0$ & $301.57^{* *}$ & 297.99 & 290.15 & $r \geq 1$ & $322.91^{* * *}$ & $r \geq 1$ & 312.97 & 321.79 \\
\hline$r \geq 2$ & $246.46^{*}$ & $r \geq 1$ & $253.33^{* * *}$ & $r \geq 1$ & 239.21 & 251.13 & 243.92 & $\mathrm{r} \geq 2$ & $265.79^{*}$ & $r \geq 2$ & 256.28 & 272.92 \\
\hline$r \geq 3$ & 198.03 & $r \geq 2$ & $201.76^{*}$ & $r \geq 2$ & 187.93 & 208.27 & 201.69 & $r \geq 3$ & 211.26 & $r \geq 3$ & 207.44 & 228.04 \\
\hline$r \geq 4$ & 154.40 & $r \geq 3$ & 154.58 & $r \geq 3$ & 144.44 & 169.41 & 163.45 & $r \geq 4$ & 162.41 & $r \geq 4$ & 162.72 & .17 \\
\hline$r \geq 5$ & 116.41 & $r \geq 4$ & 114.08 & $r \geq 4$ & 106.70 & 134.54 & 129.22 & $r \geq 5$ & 119.87 & $r \geq 5$ & 123.26 & 150.28 \\
\hline$r \geq 6$ & 82.10 & $r \geq 5$ & 78.85 & $r \geq 5$ & 72.69 & 103.68 & 98.98 & $r \geq 6$ & 88.40 & $r \geq 6$ & 88.55 & 117.39 \\
\hline$r \geq 7$ & 58.36 & $r \geq 6$ & 55.12 & $r \geq 6$ & 50.13 & 76.81 & 72.74 & $r \geq 7$ & 63.62 & $r \geq 7$ & 61.46 & 88.48 \\
\hline$r \geq 8$ & 40.54 & $r \geq 7$ & 39.17 & $r \geq 7$ & 33.17 & 53.94 & 50.50 & $r \geq 8$ & 41.60 & $r \geq 8$ & 43.56 & 63.56 \\
\hline$r \geq 9$ & 24.73 & $r \geq 8$ & 24.11 & $r \geq 8$ & 21.70 & 35.07 & 32.25 & $r \geq 9$ & 25.96 & $r \geq 9$ & 27.73 & 42.60 \\
\hline$r \geq 10$ & 14.16 & $r \geq 9$ & 11.73 & $r \geq 9$ & 12.07 & 20.16 & 17.98 & $r \geq 10$ & 15.32 & $\mathrm{r} \geq 10$ & 16.89 & 25.57 \\
\hline$r \geq 11$ & 6.63 & $r \geq 10$ & 4.78 & $r \geq 10$ & 3.92 & 9.14 & 7.60 & $r \geq 11$ & 7.12 & $r \geq 11$ & 7.45 & 12.28 \\
\hline
\end{tabular}

Notes: See notes to Table 2. This table reports the Johansen-Juselius (1992) trace statistics from multivariate cointegration tests. Given the large number of variables in the tested vectors, only two lags are used for parsimonious estimations. The critical values are from Table C.2 of Dennis et al. (2005) for systems without exogenous variables, and the critical values for systems with exogenous variables are from CATS 2.0.

To shed further light on this issue, we perform two other rounds of the $\mathrm{JJ}$ multivariate cointegration tests whereby either Japan or the US is excluded from the cointegrating vector being tested. As panel B in Table 3 shows, excluding Japan does not influence the long-run relation among the remaining markets which continue to possess three non-zero vectors. However, excluding the US market instead (see panel C in Table 3) does weaken the cointegrating relation in the region. Additional confirmation comes from multivariate $\mathrm{JJ}$ tests reported in Table 3 (panels D and E) which assign September 11, 2001, not the Asian financial crisis, a relatively stronger impact on market interdependence in the PB region. These findings seem consistent with those reported in Darrat and Zhong (2002) and suggest that the US carries more weight than Japan in the Pacific Basin region.

\subsection{Temporal Stability of Equity Market Linkages}

Results in Table 2 suggest that equity market linkages may have varied over time in response to important events. This paper pursues this aspect further using the Hansen and Johansen (1993, HJ) test of cointegration stability. The HJ procedure is particularly suited for studying the stability of cointegrating vectors over time in the context of full-information maximum likelihood estimations. Holding the short-run dynamics of the model constant at the full-sample estimates, the HJ method treats these estimates as the null hypothesis in consecutive recursive tests. In this way, any rejection of the null of cointegration stability should solely arise from a breakdown in the long-run relation, rather than from any possible drift in the underlying short-run dynamics (see Darrat and Zhong, 2005). The purpose here is to examine whether the degree of long-run linkages among the PB markets has more materially responded to the September 11 attack or the 1997 Asian crisis.

We construct the likelihood ratio (LR) statistics and compare the likelihood values obtained from each recursive sub-sample against the likelihood values computed under the restriction that the cointegrating vectors are fixed at particular constant values. Since earlier results suggest that the US market proves more important than the Japanese market in the PB region, this paper only reports the LR test results between the US and each of the PB markets (test results with Japan are available upon request). 
The Journal of Applied Business Research - July/August 2012

Volume 28, Number 4
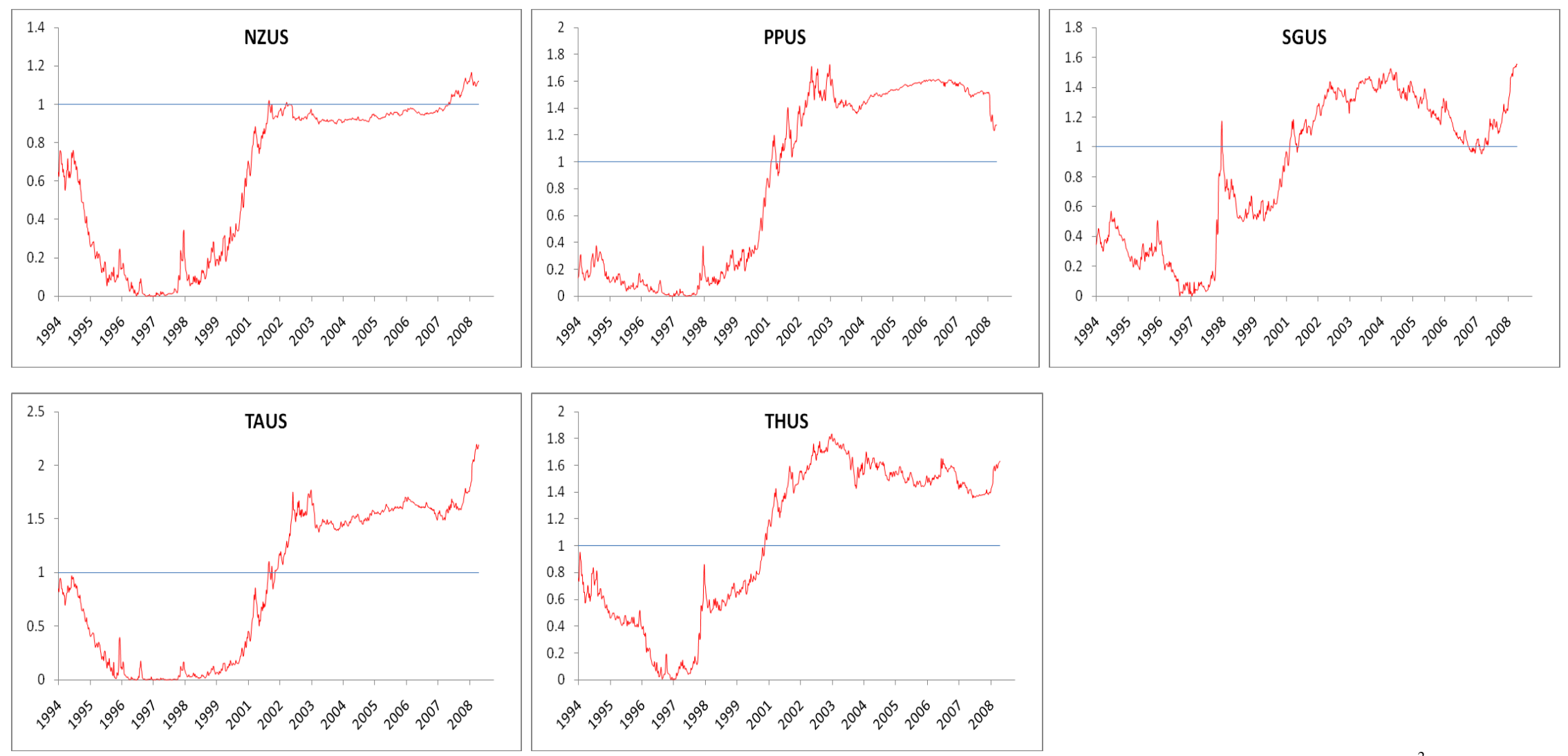

Notes: The plotted likelihood ratio statistics assess cointegration constancy using the Hansen and Johansen (1993) approach. These statistics are asymptotically $\chi^{2}$-distributed and scaled by the $5 \%$ significance level, whereby values greater than 1 imply rejection of the null hypothesis of constant cointegration parameters. The sample period for estimating $\beta_{0}$ (used in the diagnostic test) is Jan 5, 1988 - Oct 3, 1997. See notes to Table 1 for country abbreviations.

626

http://www.cluteinstitute.com/ @ 2012 The Chute Institute 
Figure 2: Test of Cointegration Constancy in a Multivariate Setting (All Twelve Markets)

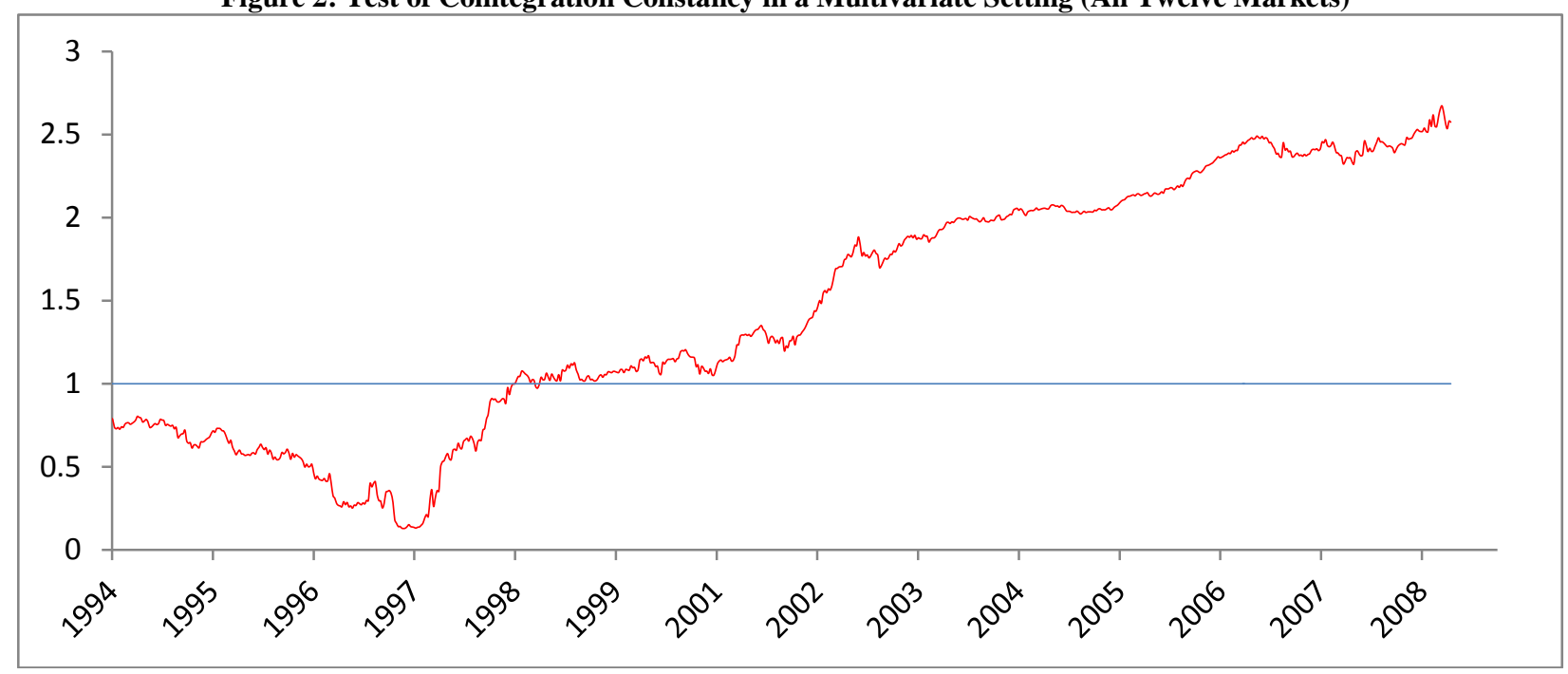

Notes: See notes to Figure 1.

Figure 1 plots the recursive statistics for all pairs between the US and each of the eleven PB markets. Normalized by the 5\% critical values, calculated statistics above one imply rejection of the null of cointegration stability. Figure 1 suggests that the cointegrating relation linking the US with almost every PB market appears to have broken down since the September 2001 terrorist attack. By contrast, the Asian crisis had only minor and temporary effects on the long-run relations between the US and each of the PB markets, and then only in the case of Malaysia and Singapore.

Results in a multivariate context (see Figure 2) corroborate the above inferences and indicate that the longrun relations between the US and the PB region had apparently collapsed since September 11, 2001. Results from a moving-window recursive cointegration test (available upon request) also convey similar inferences.

\section{WHY DO MARKET LINKAGES VARY ACROSS COUNTRIES?}

Evidence discussed in Section 3.1 suggests that the level of market linkage varies across markets in the PB region. This section discusses alternative explanations of the diverse levels of market linkage observed across countries. We first identify various ways to measure the dependent variable (cross-sectional market linkages) and then discuss results from five candidates that could explain the varied market linkages across countries in the PB region.

\subsection{Measuring the Dependent Variable (Market Linkages)}

Our first task is to find an appropriate measure of market linkages to represent the dependent variable in the cross-sectional analysis. We consider three alternative measures. The first is eigenvalues derived from the bivariate cointegration tests. The second measure is trace statistics also obtained from these same cointegration tests. Both metrics reflect the degree of market linkage. A third way of measuring market linkages derives from a probit model whose dependent variable for any market pair takes 1 if the number of cointegration vectors exceeds the average over the 66 pairs, and zero otherwise. The probit model is:

$\Delta$ probabilty $=\beta_{i} * \sigma_{i}$

where $\beta_{i}$ is the coefficient of the independent variable $i, \sigma_{i}$ is the standard deviation of variable $i$ and 
$\Delta$ probabilty measures the change in the probability of markets being linked due to one standard deviation change in variable $i$ ceteris paribus. In this context, the economic significance of variable $i$ upon market linkage may be explored.

\subsection{Possible Explanations for the Varied Market Linkages across Countries}

\subsubsection{Role of Trade}

Darrat and Zhong (2005) find greater trade ties to play an important role in strengthening linkages among equity markets. To test this hypothesis in the PB region, the estimated regressions include a dummy variable that takes 1 if the markets pair has high foreign trade volume (or being ASEAN members), and zero otherwise.

\subsubsection{Role of the Money Market}

Equity market linkages across borders could intensify under stronger money market linkages. Higher interest rates raise the cost of capital which would depress investment and push equity prices down. If the money markets in the two countries are highly linked, their interest rates tend to move together producing a tighter link between equity prices.

To approximate the effect of money market linkage in the model, this paper employs the absolute weekly interest rate differentials between the two markets. Following Bracker, Docking and Koch (1999), three-month interest rates are used to represent the money market (a shorter maturity interest rate across all countries are unavailable). Larger interest-rate differentials are hypothesized to weaken equity market linkage across countries.

\subsubsection{Level of Market Maturity}

The ability of equity markets to integrate together is likely positively related to the degree of market maturity. Following Bracker, Docking and Koch (1999), size differentials between markets represent market maturity as follows:

$$
\operatorname{sdiff}_{i, j}=\frac{A v g \ln S I_{i}}{A v g \ln S I_{j}}
$$

where $A v g \ln S I_{i}$ is the natural log of stock market capitalization $i$ computed at weekly intervals. The average of the $\log$ stock index $i$ is then calculated for the full period. The same procedure is repeated for market $j^{2}$

\subsubsection{Equity Market Volatility}

The market contagion hypothesis contends that markets tend to exhibit higher linkage as they become more volatile (Karolyi and Stulz, 1996). Yet, it is also possible that when markets undergo high volatility, risk-averse investors tend to invest domestically. This domestic over-investment is known as the home-bias puzzle. If valid, higher market volatility would inhibit (rather than enhance) cross-border capital flows, driving equity markets apart. Thus, higher market volatility can either increase or decrease market linkages across borders.

We measure market volatility by the equally weighted (average) conditional standard deviations of returns in markets $i$ and $j$. The individual conditional standard deviations are extracted from univariate GARCH $(1,1)$ models averaged over the estimation period, resulting in sixty-six equally weighted volatility measures.

\footnotetext{
${ }^{2}$ In an expanded version of this paper, we measures the degree of market maturity by the turnover ratio and also by dummy variables for large versus small markets. The results (available upon request) are qualitatively similar to those using size differentials. 


\subsubsection{Exchange-Rate Volatility}

Exchange-rate risk impacts equity markets particularly for cross-border investments and can thus impact the degree of market integration (Bodart and Reding, 1999). The exchange-rate risk may weaken or strengthen equity market integration. Higher exchange-rate volatility increases hedging costs which could weaken market linkage due to higher required returns. On the other hand, exchange-rate volatility may also induce changes in the level of foreign trade due to deviations from the purchasing power parity (PPP). The PPP implies that a country's levels of exports and imports depend on the prevailing real exchange rate. Higher exchange-rate volatility increases the probability of deviating from PPP which would increase the volume of trade across borders. As hypothesized earlier, the resulting higher foreign trade would in turn strengthen market linkage. Thus, the sign of the effect of exchange-rate volatility on the degree of market linkage can only be resolved empirically.

Bilateral exchange rates for all 66 market pairs in the PB region come from DataStream and we extract the conditional variance from univariate $\operatorname{GARCH}(1,1)$ models which represents the exchange-rate volatility.

\subsection{Cross-sectional Results}

Table 4 reports the results from the cross-sectional regressions where the standard errors are corrected for possible heteroskedasticity using the Newey-West procedure for the OLS regressions and by the Huber/White procedure for the probit regressions. Overall, the results are adequate and the OLS regressions are statistically significant at better than the $1 \%$ level in both the eigenvalues and the trace statistic regressions.

Table 4: Explaining Variations in Equity Market Linkages across Countries Panel A: Dependent Variable: Eigenvalues

\begin{tabular}{|c|c|c|c|c|c|c|c|c|c|c|}
\hline & intercept & aseand & exvol & irdiff & Vol & sdiff & & & & \\
\hline $\begin{array}{l}\text { Coefficient } \\
\text { (t-Statistic) }\end{array}$ & $\begin{array}{l}0.008^{*} \\
(1.83)\end{array}$ & $\begin{array}{c}0.000 \\
(-0.17)\end{array}$ & $\begin{array}{c}3.761^{* *} \\
(2.29)\end{array}$ & $\begin{array}{c}-3.0 \mathrm{E}-04 \\
(-1.34)\end{array}$ & $\begin{array}{l}0.130 \\
(1.41)\end{array}$ & $\begin{array}{l}-0.003 \\
(-1.17)\end{array}$ & $\begin{array}{r}\text { F-statistic } \\
\text { (p-value) }\end{array}$ & $\begin{array}{c}14.99^{* * *} \\
(0.01)\end{array}$ & Adj. $R^{2}$ & 0.10 \\
\hline \multicolumn{11}{|c|}{ Panel B: Dependent Variable: Trace Statistics } \\
\hline $\begin{array}{l}\text { Coefficient } \\
\text { (t-Statistic) }\end{array}$ & $\begin{array}{c}13.509^{* * *} \\
(2.40)\end{array}$ & $\begin{array}{l}-0.339 \\
(-0.22)\end{array}$ & $\begin{array}{c}3962.255^{* *} \\
(2.15)\end{array}$ & $\begin{array}{l}-0.349 \\
(-1.22)\end{array}$ & $\begin{array}{c}165.513 \\
(1.56)\end{array}$ & $\begin{array}{l}-3.938 \\
(-1.23)\end{array}$ & $\begin{array}{r}\text { F-statistic } \\
\text { (p-value) }\end{array}$ & $\begin{array}{c}13.84^{* *} \\
(0.02)\end{array}$ & Adj. $\mathrm{R}^{2}$ & 0.09 \\
\hline \multicolumn{11}{|c|}{ Panel C: Dependent Variable: Probability of Cointegration } \\
\hline $\begin{array}{l}\text { Coefficient } \\
\text { (t-Statistic) }\end{array}$ & $\begin{array}{l}0.402 \\
(0.16)\end{array}$ & $\begin{array}{l}-0.338 \\
(-0.59)\end{array}$ & $\begin{array}{c}20.962 \\
(0.03)\end{array}$ & $\begin{array}{l}0.009 \\
(0.09)\end{array}$ & $\begin{array}{c}84.753^{\text {*** }} \\
(2.16)\end{array}$ & $\begin{array}{l}-3.420^{*} \\
(-1.96)\end{array}$ & $\begin{array}{r}\text { F-statistic } \\
\text { (p-value) }\end{array}$ & $\begin{array}{l}12.61^{* *} \\
(0.03)\end{array}$ & Adj. $R^{2}$ & 0.18 \\
\hline
\end{tabular}

Notes: The sample period covers January 5, 1988 through to December 30, 2008. Panels A and B report OLS regression results while Panel C provides results from a probit model. aseand is a dummy variable that takes a value of 1 when markets $i$ and $j$ are both ASEAN member countries, and 0 otherwise. exvol is the volatility of the bilateral exchange rates of markets $i$ and $j$ extracted from a univariate GARCH $(1,1)$ model. irdiff is the absolute weekly interest rate differential between the two markets averaged over the estimation period. vol is the equally weighted standard deviations of market $i$ and $j$ averaged over the estimation period. The individual standard deviations are extracted from a bivariate GARCH $(1,1)$ model. All sixty-six standard deviations are derived from returns in the estimation period. sdiff is the average weekly logged market capitalization of market $i$ deflated by the average weekly logged market capitalization of market $j . \mathrm{R}^{2}$ figures in the probit results are the Mac-Fadden pseudo $\mathrm{R}^{2}{ }^{* * *},{ }^{* *},{ }^{* *}$ indicate significance at $1 \%, 5 \%, 10 \%$ level, respectively.

The OLS regressions indicate that only the exchange-rate volatility exerts statistically significant effects on the level of equity market linkage at the $5 \%$ level and that the sign is positive in both cases. Thus, contrary to Fratzscher's (2002) evidence for the European Union, our results for the PB region suggest that higher exchangerate volatility significantly promotes equity market linkages due to the departures from PPP and the ensued higher bilateral trade. As to estimates from the probit regression, the results accord instead with the contagion hypothesis. They indicate that higher stock market volatility and increased money market linkages (lower interest-rate differentials) strengthen equity market linkages across the PB region. 


\section{CONCLUDING REMARKS}

The paper investigates the degree of interdependence among the PB markets, their relation with the matured markets of the US and Japan, and examines whether the 1997 Asian crisis and the September 11, 2001 terrorist attack have influenced these market linkages. In addition, the paper searches for possible explanations for why market linkages vary across countries in the PB region. The data are weekly observations spanning the period from January 5, 1988 to December 30, 2008.

The results from cointegration tests provide compelling evidence that the PB equity markets are robustly interdependent within the region and they are also externally linked particularly to the US (rather than the Japanese) market. Robust long-run relations among equity markets, whether regionally or externally, seem inconsistent with market efficiency. As Granger (1986) demonstrates, cointegration between two or more variables (markets) implies the presence of Granger-causality in at least one direction. Such lead-lag relations could imply that stock prices in a given PB market can be predicted by information available on other markets. Nevertheless, predictability alone does not necessarily insinuate market inefficiency unless the implied trading rule can also yield risk-adjusted excess returns.

We also find strong evidence that market interdependence, whether internally within the PB region or externally with the US market, has significantly weakened particularly in the post-September 2001 regime. This weakening of equity market linkages may have strengthened diversification benefits available to US investors from investing in the PB region. Finally, cross-sectional regression analysis suggests that exchange-rate volatility, equity market volatility and money-market interlinks are major culprits behind varying degrees of equity market linkages across countries in the Pacific Basin region.

\section{ACKNOWLEDGEMENT}

The authors are grateful to Jung Park and Jason Hur for several useful comments and suggestions on an earlier draft of this paper. Bin Li is grateful for financial support from Griffith University under the 2011 Griffith University New Researcher Grant, Project Number: 40730. The usual caveat applies.

\section{AUTHOR INFORMATION}

Ali F. Darrat is the Chase Endowed Professor of Finance \& Professor of Economics at Louisiana Tech University. $\mathrm{He}$ holds BA from the University of Benghazi, and MA and Ph.D. from Indiana University (Bloomington). Professor Darrat's research covers a wide area in finance and economics including the efficiency of financial and capital markets, international finance, business cycles and the economic consequences of government budget deficits. He has published more than 170 articles in refereed finance and economics journals including Journal of Financial and Quantitative Analysis, Journal of Banking and Finance, Review of Economics and Statistics, Journal of Money, Credit and Banking, Southern Economic Journal and Journal of Business Research. His articles are extensively cited by other researchers in the fields (about 500 citations) and many of his articles have also been fully abstracted in the Journal of Economic Literature, Monetary Economics Abstract, and the CFA Digest. Recipient of numerous research awards, Professor Darrat has been recently listed among the 100 most prolific researchers in the world in the field of finance. E-mail: yarab@LaTech.edu.

Grant Colthup is a trader at Propex Derivatives in Sydney, Australia. He obtained a Bachelor of Commerce Honours (1st Class) Degree in Finance from the University of Queensland. Currently, he is also pursuing his PhD study at the University of New South Wales. His research interests are portfolio management, asset allocation, corporate finance and market microstructure.

Dr. Bin Li is a lecturer in the finance area of the Department of Accounting, Finance and Economics, Griffith University, Brisbane, Australia. He is the coordinator of the research seminar series in Finance \& Financial Planning at the department. Currently, he teaches corporate finance and corporate financial risk management at the postgraduate level.

His research is in the areas of empirical asset pricing, investments and portfolio management, applied financial econometrics, market efficiency, and volatility models. Dr. Li has made many presentations in academic 
conferences and has published 19 articles in international peer-reviewed journals such as the Journal of Banking \& Finance, the Journal of Business Research, the Australian Journal of Management, the International Journal of Business and Economics, and JASSA - The FINSIA Journal of Applied Finance.

Dr. Li received a Ph.D. in finance from the University of Queensland, a Master's degree in financial management from the University of Queensland, a Master's degree in accounting from Bond University, and a bachelor's degree in electrical engineering from Zhejiang University, China. E-mail: b.li@griffith.edu.au

Dr. Maosen Zhong is Vice President of Pureland Learning College, Toowoomba, Australia. Prior to that, he was an Associate Professor of Finance at the University of Queensland. He has taught at Kansas State University and University of Texas-Brownsville. He received his DBA in Finance from Louisiana Tech University in 1999. He has published more than 25 papers in refereed journals such as Journal of Banking and Finance, Journal of International Money and Finance, Journal of Empirical Finance, Financial Review, Journal of Financial Research, Journal of Business Finance \& Accounting, and Decision Science.

\section{REFERENCES}

1. Ammer, J. Mei J. Measuring international economic linkages with stock market data. Journal of Finance 1996; 51: 1743-1763.

2. Antell J. Vaihekoski M. International asset pricing models and currency risk: Evidence from Finland 19702004. Journal of Banking \& Finance 2007; 31: 2571-2590.

3. Baele L. Volatility spillover effects in European equity markets. Journal of Financial and Quantitative Analysis 2005; 40: 373-401.

4. Bekaert G. Harvey C.R. Time-varying world market integration. Journal of Finance 1995; 50: 403-444.

5. Bekaert G. Harvey C.R. Lundblad CT. Does Financial Liberalization Spur Growth? Journal of Financial Economics 2005; 77: 3-55.

6. Bessler D.A. Yang J. The structure of interdependence in international stock markets. Journal of International Money and Finance 2003; 22: 261-287.

7. Bodart V. Reding P. Exchange rate regime, volatility and international correlations on bond and stock markets. Journal of International Money and Finance 1999; 18: 133-151.

8. Bracker K. Docking D.S. Koch P.D. Economic determinants of evolution in international stock market integration. Journal of Empirical Finance 1999; 6: 1-27.

9. Cheung Y.W. Lai K.S. Finite-sample sizes of Johansen's likelihood ratio tests for cointegration. Oxford Bulletin of Economics and Statistics 1993; 55: 313-328.

10. Chiang T.C. Jeon B.N. Li H. Dynamic correlation analysis of financial contagion: Evidence from Asian markets. Journal of International Money and Finance 2007; 26: 1206-1228.

11. Claessens S. Forbes K.J., editors. International Financial Contagion: How It Spreads and How It Can Be Stopped. Boston: Kluwer Academic Publishing, 2001.

12. Cooper I.A. Kaplanis E.C. Partially segmented international capital markets and international capital budgeting. Journal of International Money and Finance 2000; 19: 309-329.

13. Darrat A.F. Wage growth and the inflationary process. Southern Economic Journal 1994; 61: 181-190.

14. Darrat A.F. Zhong M. Permanent and transitory driving forces in Asian-Pacific stock markets. The Financial Review 2002; 37: 35-52.

15. Darrat A.F. Zhong M. Equity market linkage and multinational trade accords: The case of NAFTA. Journal of International Finance and Money 2005; 24: 793-817.

16. Darrat A.F. Gilley O. Li B. Wu Y. Revisiting the risk/return relations in the Asian Pacific markets: new evidence from alternative models. Journal of Business Research 2010: forthcoming.

17. Dekker A. Sen K. Young M. Equity market in the Asia Pacific region: a comparison of the orthogonalized and generalized VAR approaches. Global Finance Journal 2001; 12: 1-33.

18. Dennis J.G. Hansen H. Johansen S. Juselius K. CATS in RATS, version 2. Estima 2005.

19. De Santis G. Imrohoroglu S. Stock returns and volatility in emerging financial markets. Journal of International Money and Finance 1997; 16: 56-579.

20. Engle R.F. Granger C. Cointegration and error correction representation, estimation, and testing. Econometrica 1987; 55: 251-276. 
21. Fratzscher M. Financial market integration in Europe: On the effects of EMU on stock markets. International Journal of Finance 2002; 7: 165-193.

22. Forbes K.J. Rigobon R. No contagion, only interdependence: Measuring stock market comovements. Journal of Finance 2002; 57: 2223-2261.

23. Ghosh A. Saidi R. Johnson K.H. Who moves the Asia-Pacific stock markets-US or Japan. Financial Review 1999; 34: 159-169.

24. Granger C. Developments in the study of cointegrated economic variables. Oxford Bulletin of Economics and Statistics 1986; 48: 213-228.

25. Gregory A.W. Hansen B.E. Residual-based tests for cointegration in models with regime shifts. Journal of Econometrics 1996; 70: 99-126.

26. Grewal R. Mills J.A. Mehta R. Mujumdar S. Using cointegration analysis for modeling marketing interactions in dynamic environments: methodological issues and an empirical illustration. Journal of Business Research 2001; 51: 127-144.

27. Hansen H. Johansen S. Recursive estimation in cointegrated VAR models. Working Paper, Institute of Mathematical Statistics, University of Copenhagen, 1993.

28. Hatanaka M. Time-Series-Based Econometrics of Unit Roots and Cointegration. New York: Oxford University Press, 1996.

29. Herwany A. Febrian E. Co-integration and causality analysis on developed Asian markets for risk management and portfolio selection. Working Paper No. 200909, Department of Economics, Padjadjaran University, 2009.

30. Hon M. Strauss J. Yong S. Contagion in financial markets after September 11: Myth or reality?. The Journal of Financial Research 2004; 27: 95-114.

31. Johansen S. Juselius K. Testing structural hypotheses in a multivariate cointegration analysis of the PPP and the UIP for UK. Journal of Econometrics 1992; 53: 211-244.

32. Johnson R. Soenen L. Asian economic integration and market comovement. The Journal of Financial Research 2002; 25: 141-157.

33. Juselius K. Do purchasing power parity and uncovered interest rate parity hold in the long run? An example of likelihood inference in a multivariate time-series model. Journal of Econometrics 1995; 69: 211-240.

34. Karolyi G.A. Stulz RM. Why do markets move together? An investigation of US-Japan stock return comovements. Journal of Finance 1996; 51: 951-986.

35. Kasa K. Common stochastic trends in international stock markets. Journal of Monetary Economics 1992; 29: 95-124.

36. Kearney C. The determination and international transmission of stock market volatility. Global Finance Journal 2000; 11: 1-22.

37. Koutmos G. Booth G.G. Asymmetric volatility transmission in international stock markets. Journal of International Money and Finance 1995; 14: 747-762.

38. Longin F. Solnik B. Is the correlation in international equity returns constant: 1960-1990?. Journal of International Money and Finance 1995; 14: 3-26.

39. $\mathrm{Ng}$ A. Volatility spillover effects from Japan and the US to the Pacific Basin. Journal of International Money and Finance 2000; 19: 207-233.

40. $\mathrm{Ng}$ David $\mathrm{T}$. The international CAPM when expected returns are time-varying. Journal of International Money and Finance 2004; 23: 189-230.

41. Phylaktis K. Capital market integration in the Pacific Basin region: An impulse response analysis. Journal of International Money and Finance 1999; 18: 267-287.

42. Phylaktis K. Ravazzolo F. Measuring the financial and economic integration with equity prices in emerging markets. Journal of International Money and Finance 2002; 21: 879-903.

43. Roll R. Industrial structure and the comparative behavior of international stock market indices. Journal of Finance 1992; 47: 3-41.

44. Siklos P.L. Ng P. Integration among Asia-Pacific and international stock markets. Pacific Economic Review 2001; 6: 89-110.

45. Subramanian U. Cointegration of stock markets in East Asia. European Journal of Economics 2008; 14: 84-92.

46. Srivastava A. Cointegration of Asian markets with US markets: international diversification perspectives. Global Business Review 2007; 8: 251-265. 